This is a pre-print version of a paper published in Marine Policy and should be cited as:

Pafi, M., Flannery, W. and Murtagh, B., 2020. Coastal tourism, market segmentation and contested landscapes. Marine Policy, 121, p.104189.

Link to published version: https://doi.org/10.1016/j.marpol.2020.104189 


\title{
Coastal tourism, market segmentation and contested landscapes
}

\author{
Maria Pafi ${ }^{1}$, Wesley Flannery ${ }^{1}$ and Brendan Murtagh ${ }^{2}$ \\ Queen's University Belfast \\ School of Natural and Built Environment \\ David Keir Building \\ Belfast, BT9 5AG \\ Northern Ireland, UK
}

${ }^{1}$ Corresponding Author

Email: mpafi01@qub.ac.uk

Phone: +44 (0)28 90974254

1 Email: w.flannery@qub.ac.uk

Phone: +44 (0)28 90974754

2 Email: b.murtagh@qub.ac.uk

Phone: +44 (0)28 90974742 


\begin{abstract}
Governments are increasingly adopting Blue Growth strategies as a means of promoting economic development. Although Blue Growth offers development opportunities, from a local perspective it is often concentrated in inaccessible sectors or has negative impacts on coastal communities and landscapes. We argue that to be of use to local communities, tourist experiences of coastal landscapes need to be understood from a community-led, rather than market-led, perspective. Tourist market segmentation can help reveal such experiences but has predominately been used in a narrow, econometric way by the tourism industry, market researchers and policymakers. These approaches often fail to capture the innate experiential nature of coastal tourism and often result in the production of coastal tourism that is unsympathetic to community landscape perspectives and values. To address this gap, this paper adopts an experiential tourist segmentation approach based on community experiences of coastal landscapes. Applied to data collected from a tourist survey on the west coast of Ireland, we identify five landscape experiences: well-being experiences; conscientious travel experiences; nature experiences; coastal change experiences; and cultural experiences. Based on these experiences, four alternative tourist segments with significant alignment to communities around sustainable, ethical and locally sensitised forms of tourism were identified: Blue Health Seekers; Nature Escapers; Pristine Seekers; and Heritage Explorers. The paper concludes by arguing that adopting more experiential and dialogical approaches to market segmentation will identify tourist and communities' perspectives in ways that are compatible and will reveal opportunities for more inclusive and locally accessible forms of Blue Growth.
\end{abstract}

Keywords: Coastal landscape; Wild Atlantic Way; segmentation; factor-cluster analysis; coastal tourism; Blue Growth

\title{
1. Introduction
}


The European Commission's (EC) Blue Growth Strategy (EC, 2012, 2017) highlights local economic opportunities that will arise from its implementation without fully considering the complex relationship between growth realisation, communities and coastal land- and seascapes (henceforth referred to as landscapes). The Blue Growth Strategy aims to increase the value of the maritime economy by promoting the rapid development of five sectors: biotechnology; renewable energy; aquaculture; mineral resources; and coastal and marine tourism. We argue that although Blue Growth is framed as offering development opportunities for coastal communities (EC, 2014a), from a local perspective, there is an under-appreciation of the potential negative externalities of growth and the strategy's inherent contradictions regarding the development of coastal spaces (Barbesgaard, 2018; Cohen et al., 2019; Flannery and McAteer, 2020).

Achieving the EC's Blue Growth ambitions will deepen competition for resources and new opportunities will, predominately, remain inaccessible to communities. The industrialisation of the coasts through the expansion of aquaculture and wind farms, intensifies competition for resources and space, increasing the potential for stakeholder conflict (Ellis et al., 2007). The plans required by the Maritime Spatial Planning Directive (EC, 2014) are currently being established across the EU and aim to reduce such conflicts. However, planning processes have often supressed local community counter-movements aimed at resisting the commodification of landscapes and blue assets for value extraction by the private sector (Foley et al., 2015; Clarke and Flannery, 2019). With limited capital, skills-base, and asset ownership, most communities are unable to participate in technology savvy, capital intensive Blue Growth sectors, such as biotechnology, renewable energy or aquaculture (Morrissey, 2017; Flannery et al., 2018). In contrast, tourism appears to offer more accessible and sustainable forms of growth for communities in peripheral rural areas in which traditional sectors of the economy, such as 
agriculture or small-scale fisheries, have declined (EC, 2014a; EC, 2014b). The remoteness of many coastal areas and the nature of tourism, which relies on resources and notions of peripherality embedded in local communities, make the sector one of the few Blue Growth opportunities available to coastal communities (Egberts and Hundstad, 2019). However, the transformation of the coast from working places to places of visit can create tensions (Ounanian, 2019). Many tourists visit coasts to experience specific landscapes and may be perturbed by industrial coastal vistas, which in turn, deprive coastal communities of potential revenue, job opportunities, and access to important heritage assets. Therefore, there is a clear tension between Blue Growth tourism, that seeks to capitalise on marine and coastal landscapes, and forms of Blue Growth that will industrialise these landscapes (e.g. wind farm, fishing and port developments).

Navigating the complex relationships among tourism, landscapes, coastal industrialisation and communities is vital to realising the local potential of the Blue Growth Strategy. We argue that understanding tourists' landscape experiences is a central, but often misinterpreted, component of these relationships. Much of the research and policy in coastal tourism relies on market logics, that frame visitors as uncritical consumers, rather than on in-depth research on tourists' landscape interests. We argue that tourists are far more differentiated and critical than their framing as consumers with largely fixed gazes, especially in relationship to landscapes. Therefore, if coastal tourism is the Blue Growth agenda's main contribution to local communities, there is a need to understand the tourist experience from a community perspective and to consider how these experiences may positively and negatively be impacted by other activities.

We address this issue by undertaking an experiential tourist segmentation approach based on community experiences of landscapes. Segmentation of tourist markets to capture the 
complexity of their experience is common in research and policy. However, most segmentation approaches seek to understand tourists through market-based, consumer criteria (i.e. economic, behavioural, socio-demographic) and represent tourists as "buyers" with affective tastes (AMADEUS, 2016), with the coast becoming an asset class in which tourism converts its scenic qualities into products, services and experiences to match assumed tastes (Egberts and Hundstad, 2019). This market logic frames tourists as passive consumers and elides community perspectives of landscapes in favour of misconstrued or narrow tourist identities based on buyer behaviours and price satisfaction (Bruner, 2005; Harvey, 2008). The extension of market logics into tourism has intensified, especially given the loss of traditional labour markets, cooperative businesses and the industrialisation of key sectors, such as fishing (Flannery et al., 2019). For example, the landscape of the west coast of Ireland has been re-packaged as the Wild Atlantic Way (a touristic coastal route connecting the whole Atlantic coast) via slick marketing, comparatively limited infrastructure investment, but with "spectacular success" on visitor numbers, international recognition, and tourist expenditure (Fáilte Ireland, 2015a; Fáilte Ireland, 2018). The dominance of market logic in coastal tourism means that local community voices are often absent regarding how their locality is framed for tourism consumption. Alternative views to dominant segmentations are regularly excluded, can lead to contestation around the way in which local landscapes are produced and consumed, and miss important alignments between producers, consumers, and communities in developing a sustainable tourist economy.

We argue that if segmentation studies are to enhance our understanding of the complexity of tourists' experiences, it should invest in producing knowledge about differentiated landscape experiences and pressures in a dialogical way with local communities. Undertaking tourist segmentation in this way can help inform planning around Blue Growth industries and mobilise community-led initiatives. In this context, this paper aims to: (a) critically explore the value of 
segmentation in understanding the coastal tourism sector from a community perspective; (b) elicit tourist segments from real landscape experiences of the Wild Atlantic Way, Ireland; and (c) to set out the implications for places faced with multiple Blue Growth pressures.

The paper begins with a review of the literature on tourism segmentation and how it has taken a producer-led rather than community-led approach to understand tourist values, with little consideration to the importance of landscape in the tourist experience of the coast. This sets the framework for an analysis of contestation in an Irish context by focusing on tourism pressures, coastal commodification and specific impacts of the Wild Atlantic Way. The study site and our segmentation methodology are then outlined. This is followed by a presentation of our findings from the survey. The paper concludes by highlighting the complexity of tourism consumption in contested coastal landscapes and the implications for both indigenous development strategies and locally-based tourism production.

\section{Segmentation and landscape experience}

Market segmentation in tourism research is the process of dividing the tourism market into groups of tourists that demonstrate common perspectives and behaviours (Rid et al., 2014; Weaver and Lawton, 2007). With the concurrent examination of several variables, market segmentation allows for the complexity of tourist experiences to emerge. For example, segmentation has been used by industry and policymakers to reveal consumer perspectives that are crucial to designing tourism policies, services, and marketing strategies (Dolničar, 2004; Frochot, 2005). Incorporating this knowledge into policy has considerable benefits, such as the identification of niche markets (Frochot, 2005), anticipating infrastructure demands, such as access points, facilities, or museums (Murtagh et al., 2017) and enhancing branding strategies 
(Chen and Chen, 2010). Segmentation can also be used to identify growth opportunities in isolated rural areas (Weaver and Lawton, 2007); to highlight policy gaps (Beh and Bruyere, 2007); and to align tourism and environmental management policies (Rid et al., 2014).

Although segmentation demonstrates several benefits, segmentation studies have primarily engaged with market logics and, implicitly, with how producers package the coast to maximise surplus through better knowledge of growth regimes. Whereas it is on-site experiences that predominantly affects tourist perceptions of places, the majority of segmentation studies focus on analysing pre-visitation behaviour (Chen and Tsai, 2007). These studies typically focus on three constructs: purchasing behaviours combined with socio-demographic variables (Pearce and Lee, 2005); travel motivations (Beh and Bruyere, 2007); and expected benefits from visitor experiences (Frochot, 2005). Subsequently, produced segments represent tourists primarily as "buyers" with a priori tastes and expectations that need to be matched in the supply of products, services, and experiences (AMADEUS, 2016). In terms of tourist landscape experiences, segmentation studies have distinguished typologies of tourists based on their intention to visit landscapes represented through a selection of images (Leisen, 2001). Therefore, tourist segmentation processes have largely neglected the experiential part of tourism and tend to disembed tourist from both landscapes, authentic experiences, and local communities. Market-driven segmentation may overshadow local understandings of coastal areas, the history of places and unique features of community life (Kothari and Arnall, 2017). There is a significant critical literature about the shallow renditions of coastal heritage, as often projected in state-sponsored marketing, and how they can minimise local understandings of landscape and community (Harvey, 2001, 2008; Bruner, 2005). However, much of the criticism tends to frame tourists as passive receptors of narratives carefully crafted by tourism industry to maximize consumption (Urry and Larsen, 2011). These depictions invariably cause 
contestation and tensions between local communities and tourism narratives, branding imagery and 'packaged' offers (Kothari and Arnall, 2017; Egberts and Hundstad, 2019). While tourist segmentation tends to result in the promotion of fossilised versions of picturesque, pristine. and unspoilt coasts, community perspectives are significantly different and are primarily based on quotidian experience of ordinary landscapes (Ounanian, 2019). When segmentation reproduces tourists as buyers with fixed preferences, especially as regards real or imagined landscape, it tends to privilege outsider conceptualisations of landscapes. Segmentation, therefore, tends to neglect the complex socio-cultural rituals and traditions that set-off counter-movements in the form of critical consumers who question hegemonic narratives imposed by tourism experts (Graham and Howard, 2008).

As Bruner (2005, p. 11) argues, tourists' experiences are "not given a priori” but, rather, emerge in a dialogical interplay during interactions with locals and places. Although some approaches, such as those adopting the questioning gaze, reframe the tourist as "a dialogical and questioning subject" (Gillespie, 2006, p. 27), they often only focus on social encounters between tourists and locals, with landscape only featuring as a background to such interaction. There is a need to delve into people-landscape interactions to inform a deeper understanding of the complexities of tourism segmentation. Here, community values are important, as they elucidate and delve into lived experiences with an emphasis on multi-sensory perceptions, corporeality, emotion and contestation (Knudsen, 2016; Murtagh et al., 2017).

Place attachment, identity, sense of community, sense of history and an enhanced sense of wellbeing are intricate experiential values commonly expressed by locals when it comes to the coast (Khakzad and Griffith, 2016; Brennan, 2018). 
Such values have received critical attention in the literature of community planning as they explain the way coastal landscape is valorised and contested (Devine-Wright, 2011; Batel and Devine-Wright, 2015). However, empirical studies in tourism have ignored such values in favour of behavioural, semiotic interactions. As a result, produced segments might be pragmatic, but they are separated from local experiences of landscapes and, therefore, hold limited value for communities and local planning. This study addresses this gap by segmenting tourists based on a set of values, emotions, and attitudes that local communities have identified for the landscapes of the west coast of Ireland.

\section{Methodology}

\subsection{Study site}

Ireland has adopted several Blue Growth policies, including tourism, with the west coast of Ireland being a particular focus for coastal tourism intensification strategies (HOOW, 2012; DTTS, 2015, 2018). The west coast is viewed as the premier asset of Irish tourism and features as the "cornerstone of international tourism campaigns" (Fáilte Ireland, 2008; p. 3). Recently, the west coast has been reinvented as "wild" and "unspoilt", along the Wild Atlantic Way. Conceived as Ireland's first long-drive touristic coastal route stretching along the west coast, the Wild Atlantic Way project was launched in 2014 as an $€ 8 \mathrm{~m}$ investment to rejuvenate Irish tourism (Fáilte Ireland, 2015a). Relying exclusively on existing road networks with comparatively limited investment on new infrastructure, the Wild Atlantic Way project focuses on marketing coastal landscapes and communities. The marketing campaign strategically targeted groups of tourists through a producer-led segmentation model which identified two main sectors: the culturally curious, who tend to be slightly older, independent travellers 
interested in places and landscapes of historic and cultural value; and the great escapers, who are travelling to "get away from it all", renew family bonds, and spend time in beautiful places (Fáilte Ireland, 2015b). Having identified the tourist segments, Fáilte Ireland (the National Tourism Development Authority of Ireland), represented coastal landscapes and communities along the Wild Atlantic Way, marked through a provision of viewing points, activities and relevant businesses (Fáilte Ireland, 2015a), as unique spectacles and experiences that matched the presumed desires of these sectors.

The success of the Wild Atlantic Way intensifies local resource pressures. Concurrently, the country's commitment to Blue Growth frames the west coast as a site for development of the aquaculture and offshore renewable sectors (DCENR, 2014, 2015; DAFM, 2015). These policies potentially contradict the Wild Atlantic Way portrayal of the west coast as a wild and unspoilt space and may lead to conflict between Blue Growth developers and coastal communities reliant on tourism.

The coast of Connemara (Co. Galway) on the west of Ireland was selected as our study site because images of its landscape are central to coastal tourism marketing. It also the location of inter-sectoral competition and community-industry contestation (Figure 1). With the largest Gaeltacht (Irish language speaking community) on the island, Connemara is a geographic region that has historically featured as a wild landscape with a distinctive history and culture and strong links to the Irish diaspora. The coast of Connemara is also experiencing increasing pressures from Blue Growth, such as proposed aquaculture and energy developments. Tourism intensification, Blue Growth developments, and a strong sense of local identity, has resulted in contestation over the future of coastal areas. Two coastal settlements were considered as appropriate case studies due to their contested nature: An Spidéal (Spiddal, in English), on the 
coast of Galway Bay in south Connemara; and Leenane, on the coast of Killary Harbour in north Connemara. Both are located on the Wild Atlantic Way and are connected with other Blue Growth developments, especially fishing and aquaculture (Hynes and Hanley, 2006). An

Spidéal is the proposed location for the deployment of a sub-sea ocean renewables test site in Galway Bay in 2015 (Vega and Hynes, 2017), which was opposed by local communities. Leenane is a prominent location for seafood production, with extensive mussel farms and salmon aquaculture (Cush and Varley, 2013)

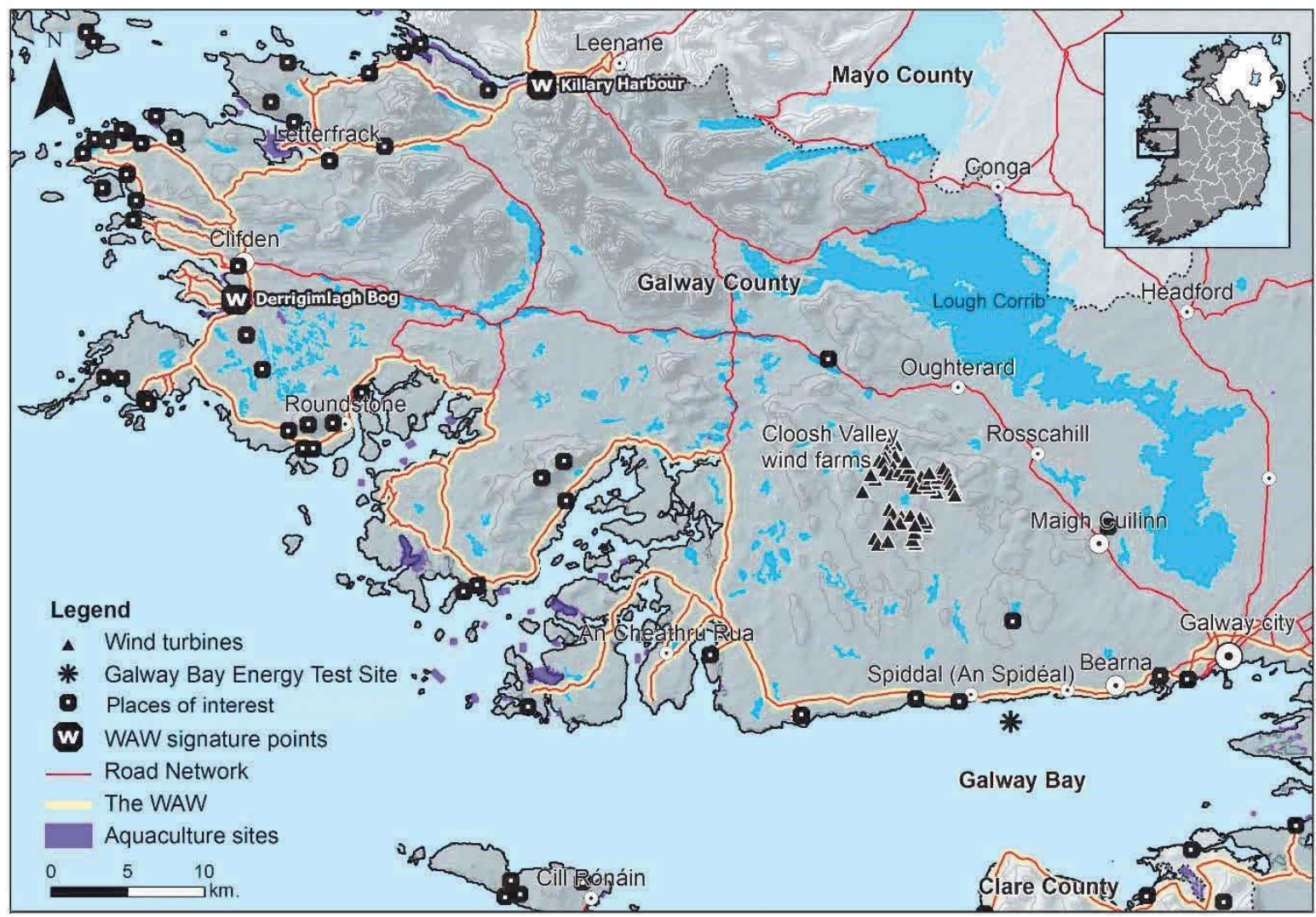

Figure 1: Coast of Connemara. Data sources: Marine Institute, 2016; DGER, 2020

\subsection{Data collection}

Our study was conducted during the summer 2018. We adopted a sequential mixed methods approach. The first stage consisted of semi-structured scoping interviews with members of the two communities. We recruited the participants through a combination of convenience and snowball sampling and asked them two questions which then instigated an open discussion: 
"What do you value most about your local place?" and "Are there any negative issues that create concerns to you?". We recorded interviews via written notes and made an effort to capture phrases verbatim. We then coded the data manually and used it for the development of the tourist survey. For example, participants from both communities identified the restorative benefits of the sea as being especially important. Accordingly, a variable was developed to reflect this value, phrased as "Being close to the ocean makes me feel healthier". Similarly, participants from both communities expressed a general belief that it is necessary to protect coastal landscapes from what were perceived as unsustainable changes, including: uncontrolled urbanisation; intensive types of tourism; the proliferation of wind farms; and extensive aquaculture. Accordingly, five variables were developed to capture these perspectives and two variables were also developed to reflect the notion of preservation (see survey in supplementary materials).

The second phase consisted of the pilot and execution the questionnaire survey. The survey included two types of variables: non-segmentation variables, which included demographic and socio-economic variables, pre-visitation motivations and awareness of the Wild Atlantic Way brand; and segmentation variables developed from the scoping interviews and phrased as values, emotions and attitudes which reflect experiences of coastal landscape. Segmentation variables were measured on a five point Likert-scale (strongly disagree to strongly agree). An open-ended question was also included to capture additional positive and negative perceptions. The survey was piloted with a group of researchers (both native and non-native English speakers) and with tourists in several locations within the study site (see Figure 1).

Segmenting by landscape experience requires collecting data on-site to capture the real-time corporeal and emotional responses. The survey was, therefore, distributed in two ways. The 
first involved recruiting the participants on-site applying convenience sampling (Pearce and Lee, 2005; Beh and Bruyere, 2007; Rid et al., 2014) at three locations and on one bus tour route along the coast. In this instance, participants were invited to self-complete and return the survey to the researchers. The second involved leaving the survey at multiple outlets along the coast (i.e. Galway City Museum, and various businesses from the tourism sector in An Spidéal and Leenane) and collecting them the end of the summer period (Table 1). In total, 505 valid surveys were retained, with an average response rate of $33 \%$ for on-site recruiting and $26 \%$ for surveys collected from coastal outlets. As it was decided not to impute missing values, only 457 surveys with zero missing values were eventually used for segmentation, while variables with high percentage of missing values were also removed.

Table 1: Response rates per location

\begin{tabular}{lccccc}
\hline & \multicolumn{3}{c}{ Recruited onsite } & \multicolumn{2}{c}{ Total } \\
\cline { 2 - 4 } & $\begin{array}{c}\text { Galway city } \\
\text { (Spanish Arch) }\end{array}$ & $\begin{array}{c}\text { Connemara } \\
\text { (several places of } \\
\text { interest) }\end{array}$ & $\begin{array}{c}\text { Connemara Bus } \\
\text { Tours }\end{array}$ & \\
Tourists sampled & 753 & & 84 & 312 & 1,149 \\
\hline Valid surveys & 227 & 22 & 126 & 375 \\
\hline $\begin{array}{l}\text { Surveys used in analysis } \\
\text { (zero missing) }\end{array}$ & 221 & 20 & 110 & 351 \\
\hline Response rate & $30 \%$ & $26 \%$ & $40 \%$ & $\mathbf{3 3 \%}$ \\
\hline
\end{tabular}

Collected from outlet

\begin{tabular}{lrrr}
\cline { 2 - 3 } & $\begin{array}{c}\text { Galway city } \\
\text { (Galway Museum) }\end{array}$ & \multicolumn{2}{c}{$\begin{array}{c}\text { Connemara (An } \\
\text { Spidéal \& Leenane) }\end{array}$} \\
\hline Surveys distributed & 250 & 250 & 500 \\
\hline Valid surveys & 112 & 18 & 130 \\
\hline $\begin{array}{l}\text { Surveys used in analysis } \\
\text { (zero missing) }\end{array}$ & 94 & 12 & 106 \\
\hline Response rate & $45 \%$ & $7 \%$ & $\mathbf{2 6 \%}$ \\
\hline \hline
\end{tabular}

3.3 Segmentation methodology

A two-step segmentation methodology was adopted, which comprises both factor and cluster analysis. This is an established methodology for tourism segmentation studies (Frochot, 2005; 
Pearce and Lee, 2005; Rid, et al, 2014). Segmentation variables were factor analysed (Principal Component Analysis with Varimax rotation) to identify the underlying dimensions of tourist coastal landscape experiences. Five components were retained, which concurrently satisfied three criteria: (1) eigenvalue of at least 1 (Hair et al., 2006); (2) factor loadings above 0.50 (Frochot, 2005); and (3) high internal consistency (Composite Reliability > 0.7 and Average Variance Extraction > 0.5) (Brunner 2005). These five components were then grouped into a set of clusters (K-means with Euclidean distance) to identify typologies of coastal tourists based on their landscape experiences. Having repeatedly tested three, four and five-cluster solutions, four clusters were retained, as this was the most stable (based on iteration history) and interpretable solution (Hair, et al., 2006). Finally, Pearson Chi-square tests were run to identify significant differences between tourist segments using the non-segmentation variables of the survey (i.e. frequency of visitation, importance of the Wild Atlantic Way on decision to visit, demographics, etc.). All the statistical analysis was performed in SPSS software.

\section{Findings}

Respondents were all over 18 years old, with a median in the age class of 25 - 34 years old. Data regarding country of residence revealed that: $38.7 \%$ of respondents came from European countries; $23.9 \%$ from North America; $16.4 \%$ from Ireland; $8.3 \%$ from Great Britain; and 4.4\% from Northern Ireland. The remaining 8.9\% came from the rest of the world. These ratios resonate with official statistics for tourism on the west coast (Fáilte Ireland, 2019). 


\subsection{Identifying experiences of coastal landscape}

Findings from the Principal Component Analysis (PCA) suggest that tourist experiences of the west coast are best represented by five components (Table 2): well-being experiences; conscientious travel experiences; nature experiences; coastal change experiences; and cultural experiences. Each component is briefly described below. The statements which loaded in each component are referenced within the text in parenthesis (i.e. v1, v2 etc.). Quotes from the open survey question are used to give context to the experiences. Quotes were taken from respondents with a high contribution (factor score $>0.70$ ) to the relevant component.

\subsubsection{Well-being experiences}

The component which accounted for the highest variance (22\%), was interpreted as representing therapeutic coastal experiences, which was labelled well-being experiences. Wellbeing experiences emphasizes intrinsic values and deeper psychological connections with the coast and sea, captured through statements that associate with specific states of mind and positive emotions. The distinguishing feature of well-being experiences is the quest for wellbeing and the therapeutic qualities of coastal landscapes. The presence of water is central in this construct, as the proximity to the ocean enables participants to "feel healthier" (v4). The statements that best express this perspective stand for spiritual values, such as freedom and eternity (v1), a sense of tranquillity (v3) and emotional attachment (v2). These variables loading together align with the notion of tranquillity, which is synonymous with feelings of calmness, quietness, peace, solitude and a sense of escape from stressful everyday life. The sea also triggers a sense of peace and well-being, as illustrated in quotes which relate to the wellbeing experiences experience:

"The best part was the coast facing the Atlantic Ocean" (Male, 18-24 years old, student, Europe). 
"the coast and the peace" (Female, 35-44 years old, teacher, Ireland).

"the power of the sea, peace and wildness together" (Male, 18-24 years

old, researcher, Canada).

Well-being experiences seems to be underpinned by a general belief that the coast and the sea are intrinsically valueable. This belief mobilizes a nostalgic concern and a sense of emotional loss over environmental degradation of waterways and the sea. The sentiment is expressed in statements around pollution:

"sad for the level of pollution of the river and the sea" (Female, 55-64

years old, education, Europe).

"The pollution of the waterways takes away from the experience" (Female, 35-44 years, currently unemployed, Ireland).

Coastal change resulting from urban sprawl (v13), wind turbines (v12), aquaculture (v11) or tourism (v5, v6) were less relevant to this experience, as evidenced by the comparatively weak loadings on these statements.

\subsubsection{Conscientious travel experiences}

Conscientious travel experiences, which accounted for $12 \%$ of the variance, was interpreted as the experience of relating with the west coast in a conscious, responsible manner. This is characterized by an increased awareness of tourism's impact on the coast, as illustrated by the two statements that received the highest loadings (v5, v6). The degradation caused at the coast by tourist facilities is central in this perspective, while the negative experience from the increasing numbers of tourists has also been captured in quotes:

"[Travelling to] learn about my ancestry [but there are] hordes of tourists everywhere" (Female, 35 - 44 years old, university professor, USA). 
Other quotes relevant to this experience, revealed a level of cynicism about " the overcommercialization of the coastal areas, especially Galway" (Female, 55-64 years old, bookseller, England), portrayed as the "areas with a lot of tourists and chain stores" (Male, 25 - 34 years old, railways engineer, Australia). The way the tourism industry has reinvented specific representations of Irishness were also highly critiqued:

"Some cliché touristy "Irish" stuff aimed at Americans" (Male, 55-64 years old, commercial director, Great Britain).

"The caricature of Irishness or how we represent ourselves with increasing stereotypes" (Female, 25 - 34 years old, mental health helpline administrator, Ireland).

This component is the one that most strongly advocates for preservation (v7), drawing on a belief that the coast is fragile, and increased human activity causes serious damage. This belief is captured in comments related to increased rubbish and waste produced by tourists and the perceived insensitivity of the 'other' as regards the coastal environment:

"I can't stand the number of tourists who don't have appreciation for the earth and litter the waterways and the land" (Female, 18 - 24 years old, student, USA).

\subsubsection{Nature experiences}

The component accounting for $9 \%$ of the variance was interpreted as representing the experience of engaging with nature. The key strand of this experience emphasizes the importance of the outdoors recreational opportunities that the west coast provides (v8) and the pleasure of being both close to nature and the environment and learning from it (v9). Nature experiences also places value on the natural resources of the west coast (v10). 
Frequent phrases and words used in the open question and which are associated with the nature experiences include: "countryside"; "clean air"; "wind", "biodiversity" and the "sounds and the smells of the sea". This shows their appreciation of nature goes beyond visual or scenic amenities to include the quality of and threat to coastal ecosystems. Related quotes include the importance of "the coastal walkways", "mountain walks" and "hiking paths in the countryside", suggesting that physical encounters with nature are embodied in attitudes about its use and social value. The therapeutic value of the coast (v4) and the need for preservation (v7) were also relevant, as indicated by the relatively lower, yet significant, loadings observed in these statements. 
Table 2: Coastal landscape experiences

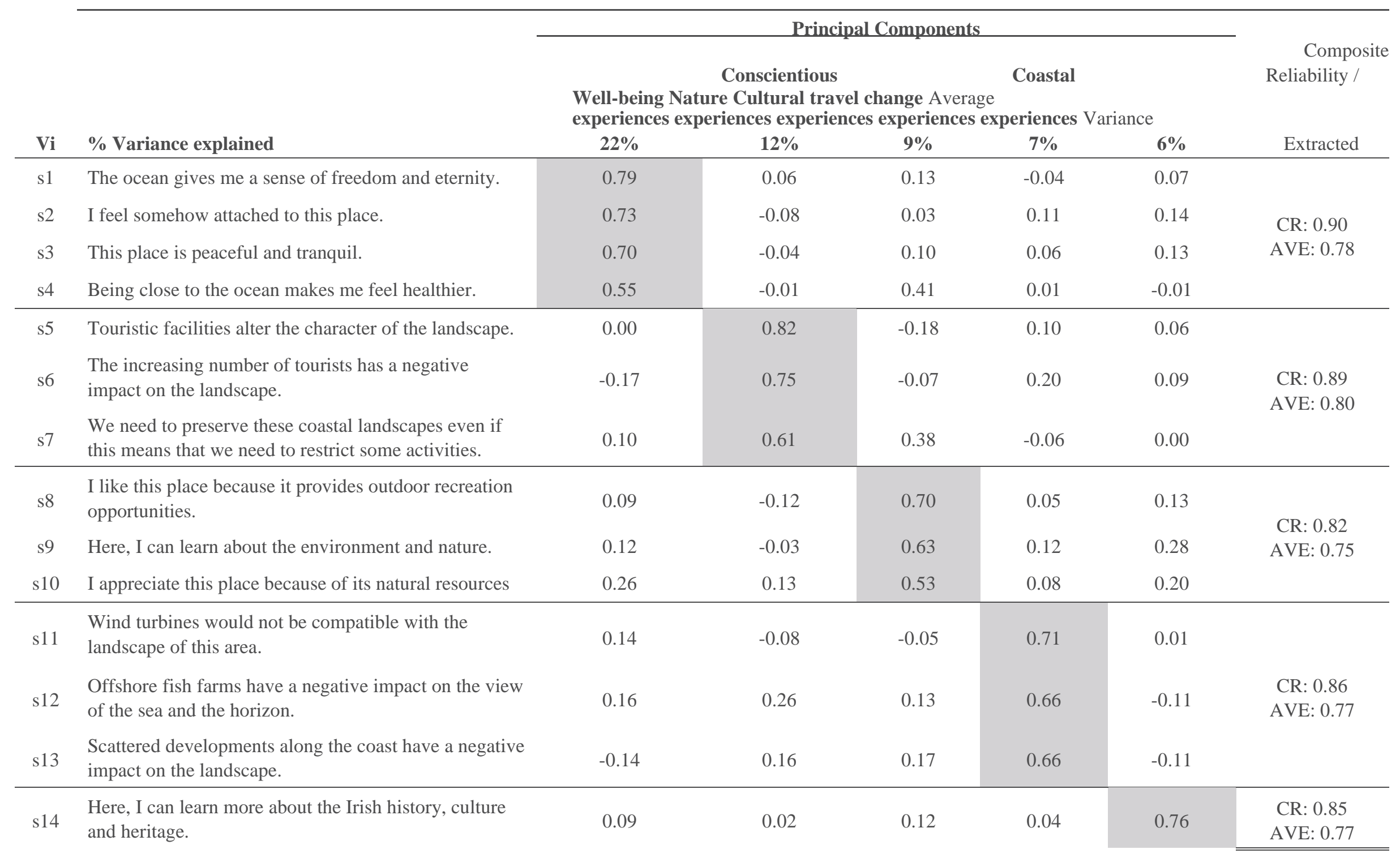


s15 I enjoy the dramatic and wild scenery.

0.02

$-0.01$

0.17

$-0.10$

0.66

There is a distinctive Irish identity embedded in this

s16 landscape.

$0.31 \quad 0.13$

0.11

$-0.13$

0.59

Notes: Sample base: 457 respondents

Extraction Method: Principal Component Analysis. Rotation Method: Varimax with Kaiser Normalization ${ }^{a}$ Rotation converged in 8 iterations. 


\subsubsection{Coastal change experiences}

The component accounting for $7 \%$ of the variance in the data, was interpreted as the experience of specifically and distinctly focusing on the contestation from urban sprawl and Blue Growth on the west coast, which labelled was labelled coastal change experiences. The experience elicited by this component emphasizes pressures from the scattered developments along the coast (v13), wind farms (v12) and aquaculture sites (v11), as demonstrated by the high loadings of the relevant statements.

The experience of observing coastal change perhaps contradicts the wild scenery (v15) and the identity of the coast (v16), as indicated by the negative loadings in these statements. This is also illustrated in negative comments about aquaculture on the basis of environmental impact because of the "bacteria and pollution" and the "visual impact and the smell; especially the smell" (Male, 55 - 64 years old, author, USA). Others focused on "the overdevelopment along the coast" (Male, 45 - 54 years old, freelancer, Ireland) and vigorously opposed this type of urbanization:

“no more buildings!!!” (Female, 25 - 34 years old, research assistant, Europe).

\subsubsection{Cultural experiences}

The component accounting for $6 \%$ of the variance, was interpreted as the experience of seek immersion in a different culture. This experience was labelled cultural experiences and involves searching for authentic experiences, which appear to be embodied in the west coast and the unique sense of Irishness it engenders. The connection to landscape and identity is central in this experience (v16), but heritage explorers demonstrate a stronger tendency towards 
consumption in comparison to the other segments. For example, the consumption of local food and drink, the pub culture and Irish music are considered integral part of the cultural experiences on the west coast of Ireland:

Friendly people, historical buildings, Irish music, pub culture (Male, 1824, student, Europe).

Landscape is appreciated for its wild and dramatic character (v15) and is mainly viewed as a "nice view" or "beautiful scenery", as indicated by the frequent use of these phrases in the open questions. The west is also portrayed as the Celtic Ireland, which is then perceived to be "the real" Ireland and in this sense, some of the participants could be said to be uniquely "Celtic consumers":

"It's beautiful, feels like the real Ireland, people are friendly and helpful" (Female, 65 years or older, retired social worker, USA).

Unlike coastal change experiences, cultural experiences do not seem to identify signs of contestation on the coast, as indicated by negative loadings in the relevant statements (v12, v13). This might be instigated by a romantic perception that this type of tourism is in balance and harmony with nature, and by extension coastal landscapes. It could also be motivated by the most iconic representations of the west of Ireland, where dispersed developments dot the coast and hence, they are perceived as the equivalent to a "rural" and by extension "authentic" way of life. Their indifferent attitude to dispersed settlement patterns and how they reflect community choices and traditions is a case in point:

"Maybe, but they [developments] make the Irish countryside special" (Female, 35 - 44 years old, teacher, USA).

Whilst others opined:

"Not if they are done in a sensitive eco-friendly manner" (Male, 44 - 55 years old, artist, Great Britain). 


\subsection{Identifying coastal tourists}

Findings from the cluster analysis suggests that tourists on the west coast are best represented by four clusters: Blue Health Seekers; Nature Escapers; Pristine Seekers; and Heritage

Explorers (Table 3 and Figure 2). The findings from Pearson's Chi-square show that there are significant differences between the clusters in variables and in particular: country of residence; type of visit; influence of the Wild Atlantic Way on decision to visit; and occupation (Table 4). This suggests that the tourist clusters are perhaps useful for developing or revisiting market segments of coastal tourism in a more marketized way. Each cluster is briefly described below, while the relationship between landscape experiences (components) and coastal tourists (clusters) has been visualised in Figure. 2.

Table 3: Coastal tourist segments

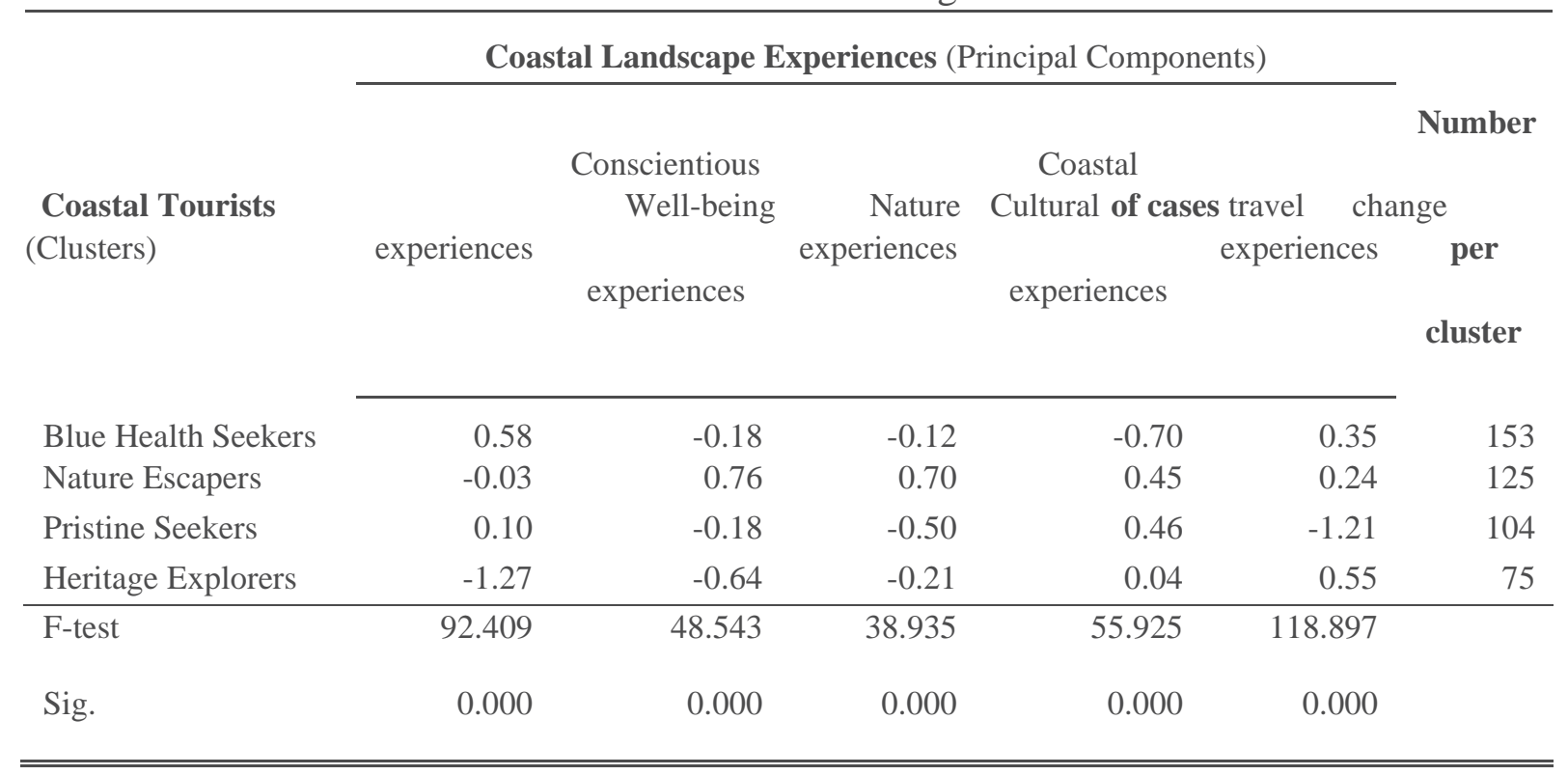

\subsubsection{Blue Health Seekers}


The cluster which grouped 153 respondents (33\% of the sample) is characterised by the quest for blue health, as evidenced by the high mean score at the well-being experiences experience $($ mean $=0.58)$. Blue Health Seekers are mainly European $(33 \%)$ and North American $(30 \%)$ but there is also a significant concentration of Irish nationals in this cluster (20\%) in comparison to the other three. As an island nation, the connection to the sea is inherently strong for many local visitors. While for other segments holidaymaking is the predominant reason for travelling, for Blue Health Seekers the reasons for travelling are slightly more varied, with $13 \%$ of Blue travelling to the coast to visit friends or relatives.

Blue Health Seekers want to connect with the marine environment and experience its therapeutic qualities. Therefore, blue assets that facilitate this experience, such as coastal promenades, beaches, piers, harbours, cliffs, rocks and seaweed, might be of high importance to this cluster. Blue Health Seekers are also interested in cultural experiences $($ mean $=0.35)$. 


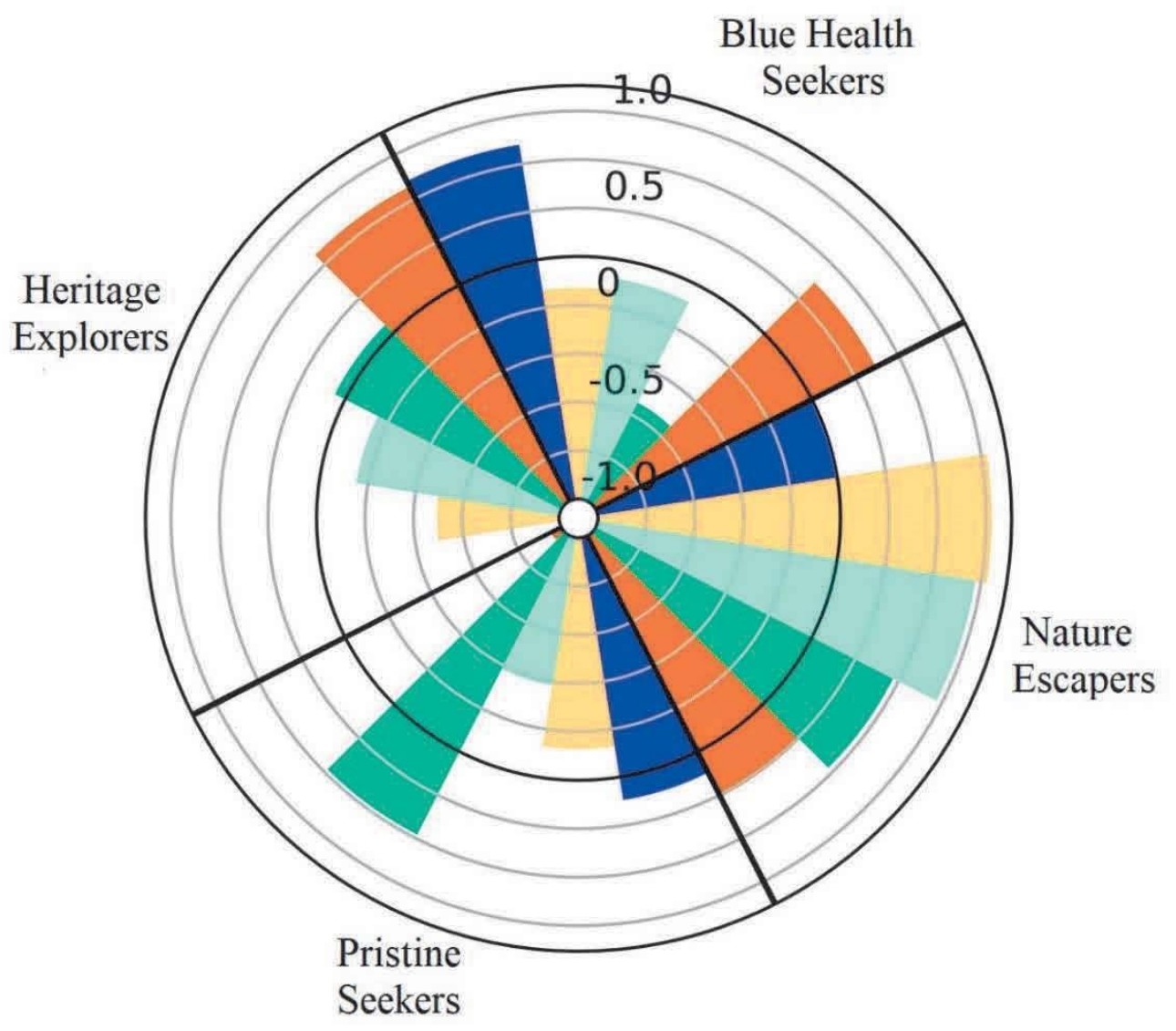

well-being experiences conscientious travel experiences nature experiences

This suggests that the maritime cultural heritage of the west coast, such as traditional boatbuilding, fishing heritage, lighthouses, shipwrecks and coastal memorials of emigration and Famine, would be of special interest to this cluster.

Figure 2: Coastal tourists and coastal landscape experiences

\subsubsection{Nature escapers}

The cluster which grouped 125 participants (27\% of the sample) emphasizes all experiences concurrently. However, the key strand that characterises this cluster is the nature experiences $($ mean $=0.70)$. The appeal of nature is also key for the Great Escapers, which is one of the two 
segments identified by the tourism industry for the Wild Atlantic Way (Fáilte Ireland, 2015b). For this reason, this cluster was labelled Nature Escapers. Nature Escapers are young (47\% below 34 years old) and predominantly European (41\%) and their main purpose for travelling to the west coast is for holidays (87\%).

The connection Nature Escapers feel for nature makes them particularly sensitive to coastal change experiences $($ mean $=0.45)$. Furthermore, Nature Escapers are highly conscious of their own impact to the host communities, as suggested by the high score at the conscientious travel experiences component (mean $=0.76)$. This suggests that increasing numbers of tourists at hotspots on the Wild Atlantic Way might potentially become a discouraging factor for Nature Escapers. On the other hand, the connection to the sea does not seem to be a key feature for Nature Escapers. This suggests that Nature Escapers are perhaps more focused on rural spaces in general rather than spaces by the sea in particular. In other words, Nature Escapers are drawn to places of high environmental quality that offer outdoor recreational opportunities regardless of whether they are blue or green. The outdoor recreational orientation of this cluster perhaps makes it a seasonal market segment.

\subsubsection{Pristine Seekers}

The cluster which grouped 116 respondents (23\% of the sample), highlights the coastal change experiences $($ mean $=0.46)$. Participants represented by this cluster demonstrate a changeaverse attitude that perhaps underlies a quest for unspoilt, pristine landscapes. Therefore, this cluster was named Pristine Seekers. Pristine Seekers are mainly represented by Europeans (41\%), while the highest concentration of visitors from Northern Ireland (8\%) is also observed in this cluster. 
Pristine Seekers are similar to Nature Escapers with regards to coastal change. They are also similar to Blue Health Seekers, as suggested by the positive mean score at the well-being experiences experience. In this context, it could be inferred that Pristine Seekers show characteristics of a niche market in the boundaries between Blue Health Seekers and Nature Escapers. What differentiates Pristine Seekers from these two clusters, is the type of visit, which is more varied for the former. For example, $12 \%$ of Pristine Seekers combined business with holidays, while $8 \%$ stated "Other" as their main reason for being at the coast. This type of response includes visitors who have moved to Ireland for a short period of time, typically less than a year, for work or study. As such, Pristine Seekers frequently visit the west coast for daytrips. The frequency of visit variable (Table 4) also suggests that Pristine Seekers are more regular to the west coast than the rest of the clusters. This suggests that Pristine Seekers might be a prominent market segment for developing year-round tourism. However, this observation needs to be taken with caution, as the relevant variable does not present statistically significant differences between clusters.

\subsubsection{Heritage Explorers}

The cluster which grouped 75 participants (16\% of the sample) emphasizes cultural experiences $($ mean $=0.55)$. As such, it was labelled Heritage Explorers. Heritage Explorers tend to be older than the rest of the clusters ( $31 \%$ above 55 years old). They are mainly from North America and Europe (33\%). There is also a relatively higher concentration of visitors from Great Britain in this cluster (15\%) in comparison to the rest of the clusters. Heritage Explorers are distinct holidaymakers (91\%) holding managerial or professional occupations (70\%) and owning their homes (62\%). This suggests that the high majority of Heritage Explorers are upper-middle class. Among all the clusters, Heritage Explorers appear to be the most influenced by tourism branding of the west coast, as evidenced by the high percent (43\%) 
that responded "a lot" in the question about the importance of the Wild Atlantic Way in their decision to visit. This is not surprising, as Fáilte Ireland has identified and targeted the Culturally Curious as a prominent segment for the Wild Atlantic Way (Fáilte Ireland, 2015b).

Table 4: Socio-demographic differences between clusters

\begin{tabular}{|c|c|c|c|c|c|}
\hline & & $\begin{array}{c}\text { Blue } \\
\text { Health } \\
\text { Seekers }\end{array}$ & $\begin{array}{c}\text { Nature } \\
\text { Escapers }\end{array}$ & $\begin{array}{l}\text { Pristine } \\
\text { Seekers }\end{array}$ & $\begin{array}{l}\text { Heritage } \\
\text { Explorers }\end{array}$ \\
\hline Survey variable & & $\begin{array}{c}33 \% \\
(\mathrm{n}=153)\end{array}$ & $\begin{array}{c}27 \% \\
(\mathrm{n}=125)\end{array}$ & $\begin{array}{c}23 \% \\
(\mathrm{n}=104)\end{array}$ & $\begin{array}{c}16 \% \\
(\mathrm{n}=75)\end{array}$ \\
\hline \multirow{4}{*}{ Frequency of visit } & First time & $\underline{61 \%}$ & $\underline{65 \%}$ & $\underline{59 \%}$ & $\underline{65 \%}$ \\
\hline & Once every few years & $18 \%$ & $\underline{22 \%}$ & $19 \%$ & $19 \%$ \\
\hline & More than once a year & $11 \%$ & $\underline{8 \%}$ & $10 \%$ & $13 \%$ \\
\hline & More than once a month & $10 \%$ & $6 \%$ & $12 \%$ & $3 \%$ \\
\hline \multirow{4}{*}{ Type of visit* } & On holiday & $76 \%$ & $87 \%$ & $69 \%$ & $91 \%$ \\
\hline & Visiting friends / relatives & $\underline{13 \%}$ & $\underline{5 \%}$ & $\underline{11 \%}$ & $\underline{8 \%}$ \\
\hline & On business & $1 \%$ & $4 \%$ & $12 \%$ & $\overline{1 \%}$ \\
\hline & Other & $9 \%$ & $4 \%$ & $8 \%$ & $0 \%$ \\
\hline \multirow{3}{*}{$\begin{array}{l}\text { Importance of } \\
\text { WAW on } \\
\text { decision to visit* }\end{array}$} & A lot & $27 \%$ & $35 \%$ & $41 \%$ & $43 \%$ \\
\hline & $\underline{\text { A little }}$ & $\underline{27 \%}$ & $\underline{22 \%}$ & $\underline{25 \%}$ & $\underline{27 \%}$ \\
\hline & None at all & $46 \%$ & $42 \%$ & $34 \%$ & $31 \%$ \\
\hline \multirow{6}{*}{ Age } & $18-24$ years & $26 \%$ & $24 \%$ & $19 \%$ & $15 \%$ \\
\hline & 25-34 years & $26 \%$ & $23 \%$ & $27 \%$ & $25 \%$ \\
\hline & $\underline{35-44 \text { years }}$ & $\underline{11 \%}$ & $13 \%$ & $\underline{21 \%}$ & $\underline{20 \%}$ \\
\hline & 45-54 years & $13 \%$ & $19 \%$ & $16 \%$ & $9 \%$ \\
\hline & $\underline{55-64 \text { years }}$ & $\underline{17 \%}$ & $\underline{13 \%}$ & $\underline{14 \%}$ & $\underline{16 \%}$ \\
\hline & 65 years or older & $7 \%$ & $9 \%$ & $2 \%$ & $15 \%$ \\
\hline \multirow{7}{*}{$\begin{array}{l}\text { Country of } \\
\text { residence } * *\end{array}$} & Republic of Ireland & $20 \%$ & $14 \%$ & $19 \%$ & $9 \%$ \\
\hline & Northern Ireland & $3 \%$ & $5 \%$ & $\underline{8 \%}$ & $3 \%$ \\
\hline & England, Wales or Scotland & $\underline{8 \%}$ & $\underline{9 \%}$ & $\underline{4 \%}$ & $\underline{15 \%}$ \\
\hline & Other European country & $33 \%$ & $4 \overline{1 \%}$ & $4 \overline{99 \%}$ & $\underline{33 \%}$ \\
\hline & USA or Canada & $\underline{30 \%}$ & $22 \%$ & $\underline{10 \%}$ & $\underline{33 \%}$ \\
\hline & Australia / New Zealand & $\underline{3 \%}$ & $\underline{2 \%}$ & $\underline{3 \%}$ & $\underline{5 \%}$ \\
\hline & Other & $5 \%$ & $6 \%$ & $8 \%$ & $1 \%$ \\
\hline \multirow{3}{*}{ Home ownership } & Own my home & $\underline{46 \%}$ & $\underline{54 \%}$ & $\underline{39 \%}$ & $\underline{62 \%}$ \\
\hline & $\underline{\text { Rent from someone else }}$ & $\underline{38 \%}$ & $\underline{34 \%}$ & $\underline{38 \%}$ & $\underline{27 \%}$ \\
\hline & Other & $16 \%$ & $12 \%$ & $22 \%$ & $11 \%$ \\
\hline \multirow[b]{2}{*}{ Occupation* } & Managerial / professional & $56 \%$ & $52 \%$ & $49 \%$ & $70 \%$ \\
\hline & $\begin{array}{l}\text { Intermediate / } \\
\text { Small employers / } \\
\text { Own account workers }\end{array}$ & $7 \%$ & $12 \%$ & $17 \%$ & $8 \%$ \\
\hline
\end{tabular}




\begin{tabular}{|c|c|c|c|c|c|}
\hline & $\begin{array}{l}\text { Lower supervisory / } \\
\text { Technical }\end{array}$ & $2 \%$ & $3 \%$ & $4 \%$ & $1 \%$ \\
\hline & $\begin{array}{l}\text { Semi-routine / } \\
\text { Routine }\end{array}$ & $16 \%$ & $11 \%$ & $12 \%$ & $8 \%$ \\
\hline & $\begin{array}{l}\text { Students / } \\
\text { Long-term unemployed }\end{array}$ & $19 \%$ & $23 \%$ & $17 \%$ & $11 \%$ \\
\hline \multirow{5}{*}{$\begin{array}{l}\text { Landscapes } \\
\text { should be changed } \\
\text { to } \\
\text { support human } \\
\text { activities, even if } \\
\text { this means...** }\end{array}$} & Strongly disagree & $52 \%$ & $60 \%$ & $63 \%$ & $25 \%$ \\
\hline & Mostly disagree & $30 \%$ & $22 \%$ & $14 \%$ & $32 \%$ \\
\hline & Neither & $13 \%$ & $14 \%$ & $15 \%$ & $29 \%$ \\
\hline & Mostly agree & $4 \%$ & $2 \%$ & $4 \%$ & $11 \%$ \\
\hline & Strongly agree & $1 \%$ & $2 \%$ & $3 \%$ & $3 \%$ \\
\hline
\end{tabular}

Notes: Sample base: 457 respondents

*Differences among clusters are significant at the 0.05 level.

**Differences among clusters are significant at the 0.01 level.

\section{Conclusions}

The production and consumption of the coast has intensified with the advent of Blue Growth policies. This both pressurises and provides opportunities for local communities. However, these opportunities may go unrealised unless the complex relationship between growth activities, coastal tourism and local communities is addressed in future policies and marine and coastal plans. We argue that tourists' landscape experiences are at the heart of these complexities and that market segmentation can be used to deepen our understanding of such experiences in ways that advantage communities rather than producers. However, segmentation has primarily adopted market-driven approaches that often fail to revel the landscape experiences of coastal tourists and has created shallow and often unrecognisable versions of place to local people. We do not seek to deny the value or validity of market segmentation but, rather, wish to reframe it so that communities can understand tourism preferences in ways that reflect their own landscape values and that may reveal their options to resist, respond or open alternatives for locally-centred Blue Growth. 
The Irish Government has committed to boosting alternatives for locally-centred coastal tourism by endorsing the need to "support communities in coastal areas through the increase in sustainable marine-based and coastal tourism activities" (GoI, 2019a; 168). Furthermore, the realisation that the relationship among coastal tourism, communities and landscapes is impermeable, is also reflected in the acknowledgment that the development of the most "promising tourism segments" needs to be done in tandem with "maintaining and enhancing the quality of the coastal places and landscapes that visitors experience during their stay" (GoI, 2019a; 87). Within this context, our study has elucidated another dimension that policy-makers could consider in the decision-making process. Adopting a more experiential and dialogical approach to market segmentation has identified perspectives that are important to both tourists and communities in ways that are often compatible, but which also open opportunities for inclusive forms of local development. Our analysis reveals a more complex tourist than the narrow "buyer" framed by industry methodologies. While Heritage Explorers and Nature Escapers are similar to segments that have already been identified by the tourism industry on the Wild Atlantic Way, known as the Culturally Curious and the Great Escapers respectively, our analysis has highlighted that these segments are highly (self-)critical, acknowledge the contradictory nature of their practice as tourists and seek to behave in more ethical and sustainable ways. Our analysis has also introduced alternative segments representing very differentiated experiences. For example, Blue Health Seekers emerged as the largest segment in our analysis, but industry-driven methodologies have failed to recognise this coastal experience. This is probably because Blue Health Seekers look for experiences that are not exclusively financial, but are focused on physical and mental health, enhanced well-being and restoration, emotional and existential connections with community and place. Tourists represented by this segment are likely to be interested in conserving and valuing the same type of assets, resources, indigenous knowledge, development models and even ideas about place 
local communities. Furthermore, Pristine Seekers are reflective and environmentally conscious tourists who understand and even empathise with the development pressures faced by host communities. Pristine Seekers is another potential segment which the tourism industry has perhaps missed while focusing on international and high-spending, yet seasonal, market segments.

The segments we have identified also align with community perspectives, values and concerns, opening up the possibility for less conflictual forms of landscape valorisation within the tourism industry. The challenge is to convert such alignments into practical projects that extract value for communities, protect and enhance their identity, and better manage the structural economic forces that have marginalised their sense of place. This will open opportunities for communities affected by tourist and other Blue Growth pressures to think about their own assets, collective effort, and solidarity business models that better capture spill-over effects. Recycling value in such sectors taps into visitor ethics and of course, raises related ethical issues about the development options open to communities. Small communities on the Wild Atlantic Way are not going to stop economic development models that support high value tourism sectors. But they can redefine value, what it means to local people and prioritise more ethical and sustainable forms of 'growth'.

Although there is no pure, indigenous, wholesome model of tourism, there are approaches that resist narrow forms of profitability in favour of more inclusive and embedded community development. For example, there have been successful co-operatives and social enterprise models, including working barns providing shelter for walkers, hostels, heritage museums and fishing tours, that tap into this direct exchange. However, most of them are generally small scale, undercapitalized and cannot compete with corporate providers. Policy can help by 
supporting: (a) the regulatory environment that preferences cooperative models; (b) access to land and property assets; (c) social finance at competitive market rates; and (d) skills development that moves beyond traditional community development models to support business planning, financial analysis and project management. These suggestions speak to a range of national policies which already exist in Ireland. For example, The Department of Rural and Community Development has recently developed a National Social Enterprise Policy for Ireland 2019-2022 (GoI, 2019b). Here, priorities should perhaps focus on effective integration across marine policy, spatial planning and social enterprise, rather than creating new policies. Similarly, emphasis should be given in vertically integrating EU policy and investment with national and regional planning and local development programmes for delivering better outcomes for coastal communities.

Developing a systematic understanding of the tourist market that reflects community preferences and needs is a tactical challenge that is valuable to local communities. Lay knowledge and anthropological narratives are useful but normative constructs that give communities a sense of the complexity of markets are also tactically important as Blue Growth will intensify the multiple pressures they face in the future. This study has identified some of these issues in a way which we hope will add value for coastal communities. However, the study presents conceptual and methodological limitations. Experiencing the landscape is a multi-layered and nuanced interplay of physical, cognitive and emotional processes. As such, it remains largely elusive in quantitative methodologies. Triangulating tourist experiences with qualitative data from the local communities can be helpful for strengthening the conceptual value of the segments. However, triangulation goes beyond the purpose of this paper and it is addressed in other publications. The segmentation methodology adopted in this paper also poses limitations. While factor analysis gleaned the underlying categories in which the coast is 
broadly experienced by tourists reflecting local values, there is an inevitable loss of information when variables are transformed into components. This limitation is acceptable in segmentation studies, yet findings need to be interpreted with caution. Furthermore, cluster analysis is an exploratory tool and as such, the outcome is one out of several possible solutions. Validating the clusters has no indicated solution in the literature. In this study, significant differences among the clusters in terms of socio-demographic variables support the assumption that the clusters represent a valid split into potential market segments. However, the decision about the number of segments was subjective and based on repeated trials and interpretation. This suggests that many solutions are valid, if they are useful for coastal communities, coastal tourism and marine policy. Further research and experimentation is needed to convert these clusters into market segments and the use of market intelligence to develop services, products and facilities that build strong indigenous economies that protect landscapes, heritage, intangible assets and memories of coastal communities.

\section{Acknowledgement}

This research is funded by the Cullen Fellowship (Grant-Aid Agreement No.CF/15/08) carried out with the support of the Marine Institute and funded under the Marine Research Programme 2014-2020 by the Irish Government. This research has also received a grant award from the Landscape Research Group (LRG 2018 awards: Borders, boundaries and landscape justice). Wesley Flannery's and Brendan Murtagh's contributions were partly funded through the PERICLES project, which has received funding from the European Union's Horizon 2020 research and innovation programme under grant agreement No 770504. 


\section{References}

AMADEUS (2016) Future Traveler Tribes 2030: Building a more rewarding journey. Available at: https://amadeus.com/documents/en/blog/pdf/2015/07/amadeus-traveller-tribes-2030-airline-it.pdf (accessed 30 April 2019).

Barbesgaard, M. (2018) 'Blue growth: savior or ocean grabbing?', Journal of Peasant Studies, 45(1), pp. 130-149. doi: 10.1080/03066150.2017.1377186.

Batel, S. and Devine-Wright, P. (2015) 'Towards a better understanding of people's responses to renewable energy technologies: Insights from Social Representations Theory', Public Understanding of Science, 24(3), pp. 311-325. doi: 10.1177/0963662513514165.

Brennan, R. (2018) 'Re-storying marine conservation: Integrating art and science to explore and articulate ideas, visions and expressions of marine space', Ocean and Coastal Management, 162, pp. 110126. doi: 10.1016/j.ocecoaman.2018.01.036.

Beh, A. and Bruyere, B. L. (2007) 'Segmentation by visitor motivation in three Kenyan national reserves', Tourism Management, 28(6), pp. 1464-1471. doi: 10.1016/j.tourman.2007.01.010.

Bruner, E. (2005) Culture on Tour: Ethnographies on Travel. Chicago: The University of Chicago. Brunner, M. (2005) 'Analyzing the Reliability of Multidimensional Measures: An Example from Intelligence Research', Educational and Psychological Measurement, 65(2), pp. 227-240. doi: $10.1177 / 0013164404268669$.

Burgess, M. G. et al. (2018) 'Five rules for pragmatic blue growth', Marine Policy, 87(2018), pp. 331-339. doi: 10.1016/j.marpol.2016.12.005.

Chen, C. F. and Chen, F. S. (2010) 'Experience quality, perceived value, satisfaction and behavioral intentions for heritage tourists', Tourism Management, 31(1), pp. 29-35. doi: 10.1016/j.tourman.2009.02.008.

Chen, C. F. and Tsai, D. C. (2007) 'How destination image and evaluative factors affect behavioral intentions?', Tourism Management, 28(4), pp. 1115-1122. doi: 10.1016/j.tourman.2006.07.007.

Clarke and Flannery (2019) 'The post-political nature of marine spatial planning and modalities for its re-politicisation', Journal of Environmental Policy and Planning, 22(2), pp. 170-183. doi: 
10.1080/1523908X.2019.1680276.

Cohen, P.J. et al. (2019) 'Securing a just space for small-scale fisheries in the blue economy', Frontiers in Marine Science, 6(171), pp. 1 - 8. doi: 10.3389/fmars.2019.00171.

Cush, P. and Varley, T. (2013) 'Cooperation as a survival strategy among west of Ireland small-scale mussel farmers", Maritime Studies, 12(11): pp. 1 - 17. doi: 10.1186/2212-9790-12-11.

DAFM (2015) National Strategic Plan for Sustainable Aquaculture Development. Dublin. Available at:

https://www.agriculture.gov.ie/media/migration/seafood/marineagenciesandprogrammes/nspa/Nati onalStrategicPlanSusAquaDevel181215.pdf (accessed August 2019).

DCENR (2014) Offshore Renewable Energy Development Plan A Framework for the Sustainable Development of Ireland's Offshore Renewable Energy Resource. Dublin. Available at: https://www.dccae.gov.ie/documents/20140204\%20DCENR\%20\%20Offshore\%20Renewable\%20Energy\%20Development\%20Plan.pdf (accessed August 2019).

DCENR (2015) Ireland's Transition to a Low Carbon Energy Future. Dublin. Available at: https://www.dccae.gov.ie/enie/energy/publications/Documents/2/Energy\%20White\%20Paper\%20\%20Dec\%202015.pdf (accessed August 2019).

Devine-Wright, P. (2011) 'Place attachment and public acceptance of renewable energy: A tidal energy case study', Journal of Environmental Psychology, 31(2011), pp. 336-343. doi: 10.1016/j.jenvp.2011.07.001.

DGER (2020) 'Ireland's Open Data Portal'. Available at: data.gov.ie (accessed July 2020).

Dolničar, S. (2004) 'Beyond "Commonsense Segmentation": A Systematics of Segmentation Approaches in Tourism', Journal of Travel Research, 42(3), pp. 244-250. doi: $10.1177 / 0047287503258830$.

DTTS (2015) People, Place and Policy - Growing Tourism to 2025. Dublin. Available at: http://www.dttas.ie/sites/default/files/publications/tourism/english/people-place-andpolicygrowing-tourism-2025/people-place-and-policy-growing-tourism-2025.pdf (accessed August 2019). 
DTTS (2018) Tourism Action Plan 2019-2021. Dublin. Available at:

http://www.dttas.ie/tourism/publications/english/tourism-action-plan-2019-2021 (accessed 30

April 2019).

EC (2012) COMMUNICATION FROM THE COMMISSION TO THE EUROPEAN PARLIAMENT,

THE COUNCIL, THE EUROPEAN ECONOMIC AND SOCIAL COMMITTEE AND THE

COMMITTEE OF THE REGIONS: Blue Growth opportunities for marine and maritime

sustainable growth. COM (2012) 494 final. Brussels. Available at:

https://ec.europa.eu/maritimeaffairs/sites/maritimeaffairs/files/docs/body/com_2012_494_en.pdf

(accessed August 2019).

EC (2014a) COMMUNICATION FROM THE COMMISSION TO THE EUROPEAN PARLIAMENT,

THE COUNCIL, THE EUROPEAN ECONOMIC AND SOCIAL COMMITTEE AND THE

COMMITTEE OF THE REGIONS: A European Strategy for more Growth and Jobs in Coastal and

Maritime Tourism. COM(2014) 86 final. Brussels. Available at:

https://ec.europa.eu/maritimeaffairs/publications/european-strategy-more-growth-and-jobs-

coastaland-maritime-tourism_en (accessed August 2019).

EC (2014b) Guidance on Community-led Local Development in European Structural and Investment

Funds. Version 3: June 2014. Brussels. Available at:

https://ec.europa.eu/regional_policy/sources/docgener/informat/2014/guidance_community_local_ development.pdf (accessed August 2019).

EC (2017) COMMISSION STAFF WORKING DOCUMENT: Report on the Blue Growth Strategy

Towards more sustainable growth and jobs in the blue economy. SWD(2017) 128 final. Brussels.

Available at: https://ec.europa.eu/maritimeaffairs/sites/maritimeaffairs/files/swd-2017-128_en.pdf

(accessed August 2019).

Egberts, L. and Hundstad, D. (2019) 'Coastal heritage in touristic regional identity narratives: a comparison between the Norwegian region Sørlandet and the Dutch Wadden Sea area', International Journal of Heritage Studies, 0(0), pp. 1-15. doi: 10.1080/13527258.2019.1570310.

Ellis, G., Barry, J. and Robinson, C. (2007) 'Many ways to say "no", different ways to say "yes": Applying Q-Methodology to understand public acceptance of wind farm proposals', Journal of 
Environmental Planning and Management, 50(4), pp. 517-551. doi:

$10.1080 / 09640560701402075$.

Fáilte Ireland (2008) Visitor Attitudes on the Environment - Wind Farm 2008/ No. 3. Dublin.

Available at:

http://www.failteireland.ie/FailteIreland/media/WebsiteStructure/Documents/3_Research_Insights/

4_Visitor_Insights/Visitor-Attitudes-on-the-Environment.pdf?ext=.pdf (accessed August 2019).

Fáilte Ireland (2015a) Wild Atlantic Way Operational Programme 2015-2019. Dublin. Available at: http://www.failteireland.ie/FailteIreland/media/WebsiteStructure/Documents/2_Develop_Your_Bu siness/Key\%20Projects/Wild-Atlantic-Way-Operational-Programme_1.pdf (accessed August 2019).

Fáilte Ireland (2015b) Global segmentation. Available at:

http://www.failteireland.ie/Internationalsales/International-sales.aspx (accessed 30 April 2019).

Fáilte Ireland (2018) Tourism Facts 2017. Available at:

http://www.failteireland.ie/FailteIreland/media/WebsiteStructure/Documents/3_Research_Insights/

5_International_Tourism_Trends/Tourism-Facts-2017_2.pdf?ext=.pdf (accessed 30 April 2019).

Fáilte Ireland (2019) Key Tourism Facts 2018. Available at:

https://www.failteireland.ie/FailteIreland/media/WebsiteStructure/Documents/3_Research_Insights /Key-Tourism-Facts-2018.pdf?ext=.pdf (accessed 7 July 2020).

Flannery, W. et al. (2016) 'Exploring the winners and losers of marine environmental governance/Marine spatial planning: Cui bono?/“More than fishy business”: epistemology, integration and conflict in marine spatial planning/Marine spatial planning: power and scaping/Surely not all ', Planning Theory and Practice, 17(1), pp. 121-151. doi: 10.1080/14649357.2015.1131482.

Flannery, W., Healy, N. and Luna, M. (2018) 'Exclusion and non-participation in Marine Spatial Planning, Marine Policy, 88, pp. 32-40. doi: 10.1016/j.marpol.2017.11.001.

Flannery, W., Clarke, J. and McAteer, B. (2019) 'Power and Politics in Marine Spatial Planning', in Zaucha, J. and Gee, K. (eds) Maritime Spatial Planning: Past, Present, Future. Palgrave 
MacMillan, pp. 201-2017. doi: 10.1007/978-3-319-98696-8_9.

Flannery, W. and McAteer, B. (2020) 'Assessing marine spatial planning governmentality', Maritime Studies, doi: 10.1007/s40152-020-00174-2.

Foley, P., Mather, C. and Neis, B. (2015) 'Governing enclosure for coastal communities: Social embeddedness in a Canadian shrimp fishery', Marine Policy, 61, pp. 390-400. doi: 10.1016/j.marpol.2014.11.009.

Frochot, I. (2005) 'A benefit segmentation of tourists in rural areas: A Scottish perspective', Tourism Management, 26(3), pp. 335-346. doi: 10.1016/j.tourman.2003.11.016.

Gillespie, A. (2006) 'Tourist Photography and the Reverse Gaze', Ethos, 34(3), pp. 343-366. doi: 10.1525/eth.2006.34.3.343.

Government of Ireland (2019a) National Marine Planning Framework - Consultation Draft. Dublin. Available at: https://www.housing.gov.ie/planning/maritime-spatial-planning/maritimespatialplanning-directive/maritime-spatial-planning (accessed July 2020).

Government of Ireland (2019b) National Social Enterprise Policy for Ireland 2019-2022. Dublin. Available at: https://www.gov.ie/en/campaigns/e779c3-socialenterprisepolicy/\#: :text=The $\% 20$ objective $\% 20$ of $\% 20$ the $\% 20$ Policy,grow $\% 20$ in $\% 20$ scale $\% 20$ and $\% 20$ impa ct.\&text=The $\% 20$ National $\% 20$ Social $\% 20$ Enterprise $\% 20$ Policy, with $\% 20$ communities $\% 20$ and $\% 20$ disadvantaged\%20groups (accessed July 2020).

Graham, B. and Howard, P. (2008) 'Introduction: Heritage and Identity', in Graham, B. and Howard, P. (eds) The Ashgate Research Companion to Heritage and Identity. Surrey, England: ASHGATE, pp. 1-15.

Hair, J. F. et al. (2006) Multivariate Data Analysis (6th ed.), Upper Saddle River, NJ: Pearson Education. doi: 10.1198/tech.2007.s455.

Harvey, D. (2001) 'Heritage pasts and heritage presents: Temporality, meaning and the scope of heritage studies', International Journal of Heritage Studies, 7(4), pp. 319-338. doi: $10.1080 / 13581650120105534$. 
Harvey, D. (2008) 'The History of Heritage', in Graham, B. and Howard, P. (eds) The Ashgate Research Companion to Heritage and Identity. Surrey, England: ASHGATE, pp. 19-36.

Hynes, S. and Hanley, N. (2006) 'Preservation versus development on Irish rivers: whitewater kayaking and hydro-power in Ireland", Land Use Policy, 23 (2): 170-180.

HOOW (2012) Harnessing Our Ocean Wealth: An Integrated Marine Plan for Ireland. Dublin. Available at: https://oar.marine.ie/handle/10793/810 (accessed August 2017).

Khakzad, S. and Griffith, D. (2016) 'The role of fishing material culture in communities' sense of place as an added-value in management of coastal areas', Journal of Marine and Island Cultures. doi: 10.1016/j.imic.2016.09.002.

Knudsen, D. C. (2016) 'Insiders and Outsiders in Thy', in Knudsen, D. C. et al. (eds) Landscape, Tourism and Meaning. London and New York: Routledge Taylor \& Francis Group. Ebook version. Chapter 9.

Kothari, U. and Arnall, A. (2017) 'Contestation over an island imaginary landscape: The management and maintenance of touristic nature', Environment and Planning A, 49(5), pp. 980-998. doi: $10.1177 / 0308518 X 16685884$.

Leisen, B. (2001) 'Image segmentation: The case of a tourism destination', Journal of Services Marketing, 15(1), pp. 49-66. doi: 10.1108/08876040110381517.

Marine Institute (2016) 'Ireland's Marine Atlas - Access to Ireland's marine data and related information'. Available at: atlas.marine.ie (accessed July 2020).

Morrissey, K. (2017) 'It's not just a Blue Economy moment...', Dialogues in Human Geography, 7(1), pp. 42-44.

Murtagh, B., Boland, P. and Shirlow, P (2017) 'Contested heritages and cultural tourism’, International Journal of Heritage Studies, 23 (6), pp. 506-520. doi: $10.1080 / 13527258.2017 .1287118$

Ounanian, K. (2019) 'Not a "museum town”: discussions of authenticity in coastal Denmark', Journal of Tourism and Cultural Change, 17(3), pp. 285-305. doi: 10.1080/14766825.2018.1456544. 
Pearce, P. L. and Lee, U.-I. (2005) 'Developing the Travel Career Approach to Tourist Motivation', Journal of Travel Research, 43(3), pp. 226-237. doi: 10.1177/0047287504272020.

Rid, W., Ezeuduji, I. O. and Pröbstl-Haider, U. (2014) 'Segmentation by motivation for rural tourism activities in The Gambia', Tourism Management, 40(2014), pp. 102-116. doi: 10.1016/j.tourman.2013.05.006.

Urry, J. and Larsen, J. (2011) The tourist gaze 3.0. 3rd edn. SAGE. doi: 10.4135/9781446251904. Vega, A. and Hynes, S. (2017) Ireland's ocean economy Report 2017, SEMRU Report Series.

Galway. Available at: http://www.nuigalway.ie/media/researchsites/semru/files/Semru--IrelandsOcean-Economy-2017_FINALonline.pdf (accessed August 2019).

Weaver, D. B. and Lawton, L. J. (2007) 'Twenty years on: The state of contemporary ecotourism research', Tourism Management, 28(5), pp. 1168-1179. doi: 10.1016/j.tourman.2007.03.004. 